\title{
DA PRÁTICA DA DENÚNCIA À EMERGÊNCIA DE UMA PEDAGOGIA DO OLHAR: UMA BREVE GENEALOGIA SOBRE A HERMENÊUTICA NO CINEMA
}

\author{
FROM THE PRACTICE OF DENUNCIATION TO THE EMERGENCE OF A \\ PEDAGOGY OF THE EYE: A BRIEF GENEALOGY \\ ON HERMENEUTICS IN CINEMA
}

Fábio de Godoy Del Picchia Zanoni ${ }^{1}$

\begin{abstract}
RESUMO: A contrapelo das origens nobres que o campo cinematográfico tende a atribuir a si, a presente argumentação teve início não com uma reflexão em torno de práticas culturais atemporais que exibiriam em germe o devir do cinema, mas com a análise de certas práticas médicas e jurídicas inventadas no século XVIII e XIX. Ao tornar patente que o modo de avaliar um filme não nasceu no interior do que hoje entendemos como campo cinematográfico, abrimos o caminho para verificar como as práticas atinentes ao cinema possuem uma proveniência não cinematográfica. É a partir da entrada em cena das práticas da denúncia e do julgamento que saltamos da ênfase na hermenêutica sobre os filmes rumo à análise das condições de possibilidade de tais modos de descrição dos afazeres cinematográficos. Em suma, trata-se de tentar analisar a imbricação entre o campo cinematográfico e o campo pedagógico à luz do conceito de biopoder, entendido, aqui, como um dispositivo de controle social que pretende zelar pela regulação dos jogos de verdade no interior das práticas sociais, em geral, e das práticas cinematográficas, em particular.

Palavras-chave: Cinema; Direito; Medicina; Denúncia; Julgamento; Bipoder.
\end{abstract}

\begin{abstract}
Contrary to the noble origins that the cinematographic field tends to attribute to itself, the present argumentation began not with a reflection on timeless cultural practices that would exbibit in germ the becoming of cinema, but with the analysis of certain medical and juridical practices invented in the eighteenth and nineteenth centuries. By making clear that the way to evaluate a film was not born within what we now understand as a film field, we have opened the way to verify how cinema practices have a non-cinematic origin. It is from the entrance of the practices of denunciation and judgment that we jump from the emphasis on hermeneutics on films to the analysis of the conditions of possibility of such modes of description of the cinematographic affairs. In short, it is a question of trying to analyze the imbrication between the cinematographic field and the pedagogical fields in the light of the concept of biopower, understood, here, as a device of social control that tries to watch over the regulation of games of truth making within social practices, in general, and of the cinematographic practices, in particular.
\end{abstract}

Keywords: Cinema; Law; Medicine; Delation; Judgment; Biopower.

\section{INTRODUÇÃO}

Um juiz que começa por ser o acusado e a testemunha e que não julga; que simplesmente separa as terras das águas para que no fim, algum dia, uma pátria de homens nasça de um amanhecer enevoado, nas margens de um tempo mais limpo (Cortázar, 2011, p.59).

1 Professor Doutor da Universidade do Estado do Amapá. Orcid: http://orcid.org/0000-0002-3033-3151 
A questão de fundo que orientou o presente itinerário de pesquisa é: o que uma comunidade de espectadores acredita poder fazer para que as manifestações artísticas, em geral, e o cinema, em particular, aprimorem suas realizações estéticas e éticas?

A esmagadora maioria dos ativistas que caminha sob o sol da contemporaneidade parece depositar sua energia política na aposta de que abalroar uma obra ficcional seria capaz de transformar algo na ordem factual e cotidiana de suas causas, seja por meio de contenção judicial, seja por meio de inibição ideológica e crítica, como se barrar o avanço de um bem cultural equivalesse a conter ideias, práticas e hábitos supostamente perniciosos a uma população. É notória a predisposição emocional e cognitiva dos espectadores para avaliar qualquer obra a partir dos parâmetros das doutrinas a que aderem, reivindicando o ajuste dela de modo a adequar-se aos limites daquelas. Inquieta com isso, esta investigação visou tecer algumas aproximações genealógicas a respeito de como o chamado trabalho do olhar (DIDI-HUBERMAN, 2011), entre outras atividades constitutivas do sujeito, foi talhado por olhares estranhos ao cinema.

De início, carece pontuar que, assim como a matemática "não faz precisamente exigências éticas particulares" (SCHELLING, 2001, p.46), tampouco se calculariam exatamente naturais as atuais conclamações éticas para assistir corretamente ao cinema. Caminhando na contemporaneidade sobre o solo de sistemas de consagração cultural já consolidados, a criação cinematográfica (com seus críticos, revistas de cinema, festivais de cinema, etc.) pode ser lastreada historicamente, bem como os saberes que lhe delimitam, incluindo os críticos e as regras às quais se supõe dever obediência. Essa longa história não precisaria necessariamente abrir-se com os irmãos Lumière apresentando seu produto em um grande salão parisiense.

"Assistimos à gênese de uma nova arte" (JAKBSON, 2015, p.153), sentenciava Roman Jakobson, em 1933. Quem se arriscar a levar a cabo certo alargamento e lateralização do pensamento a respeito das dinâmicas culturais em voga na contemporaneidade, não se poderá furtar à ruminação vagarosa e alerta sobre o mais vultoso, pregnante e recente fenômeno da cultura de massa do século XX: o cinema. A esse respeito, já ponderavam, em alarde, autores eminentes, entre eles, Walter Benjamin, especialmente em seu ensaio $A$ obra de arte na era de sua reprodutibilidade técnica (BENJAMIN, 2012), talvez uma das obras mais influentes para o balizamento das reflexões estéticas da modernidade. Quaisquer que sejam as diferenças - e não são poucas - entre esse texto fundamental e a presente investigação, resta indubitavelmente um substrato comum, ao qual devemos, a partir de agora, fincar os dois olhos: o cinema possui uma história.

Ninguém cambalearia em dúvida, imagina-se, ante o caráter vago disso. No entanto, um tal cruzamento de ideias visa apresentar um adendo fulcral. No interior desse aparente emparelhamento disciplinar, disfarça-se um prodigioso e radical contraste relativo à perspectivação do objeto de estudo. Para elucidar a constituição histórica do cinema, mais especificamente a do espectador de cinema, optou-se, aqui, por inscrevê-la em um quadro histórico que extrapolasse as fronteiras do cinema. O que isso quererá dizer?

Ofertam-se incalculáveis scripts para o arremesso do investigador a quadros históricos atinentes à constituição do ser do espectador. A começar pela história interna do cinema. Solidarizar de modo quase obsessivo a maneira de ser do espectador às narrativas fílmicas constitui uma das cuidadosas estratégias seguidamente mobilizada pelos pesquisadores dos mais variados campos disciplinares. Já nas primeiras linhas, distinguir-se-á como não tratamos do cinema

PRACS: Revista Eletrônica de Humanidades do Curso de Ciências Sociais da UNIFAP https://periodicos.unifap.br/index.php/pracs ISSN 1984-4352 Macapá, v. 12, n. 1, p. 77-92, jan./jun. 2019 
a partir de seu desenvolvimento interno, como se os feitos cinematográficos, tal como os conhecemos hoje, fossem o único modo de fornecer inteligibilidade próprio campo cinematográfico. Nas páginas que o leitor percorrerá, não se corre o risco do enfado das narrativas muito requentadas acerca do progressivo apuramento técnico e narrativo das atividades cinematográficas, invariavelmente balizadas pela antologia de determinadas peças fílmicas. Seria um erro acreditar que o gesto analítico em causa consiste em dar azo à crença de que a história do cinema resultaria da grande síntese dos avanços técnicos dos realizadores mais arrojados, de um lado, e do progresso irrefreável dos esquemas de percepção dos espectadores, de outro.

Forçar os remos dessa andança cognitiva em direção oposta à vaga das histórias internas do cinema não é, das tarefas, a mais evidente. Quanto mais não seja porque isso implica arrancar minuciosamente do anonimato os vetores de força constitutivos do cinema que se situavam em posições excêntricas à autocompreensão atual de que se vale para pensá-lo. Sem antecipar o que teremos ocasião de examinar vagarosamente, assim sumarizaríamos o tratamento dado ao objeto de inquirição que pretendemos pormenorizar: a razão maior desse périplo narrativo ocupado da constituição histórica da experiência cinematográfica como expressão privilegiada de um movimento mais amplo de judicialização (e, como veremos, também de medicalização) do tecido social não foi outro senão o de rastrear proveniências não cinematográficas como princípio de explicação do funcionamento interno do cinema e, no mesmo golpe, sondar a extensão dos ecos produzidos pela intensificação do hábito de assistir ao cinema entre a população.

Tratando-se, no que se avança, não de uma história interna do cinema, nem de uma história cultural empenhada em enquadrar o cinema dentro de um diagnóstico sociologizante cujas incidências adviriam de outras instâncias sociais. Provocaria violência traçar as vicissitudes das linhas de força constitutivas da experiência cinematográfica a partir de um fenômeno que não entreteceria afinidades com o cinema, a saber, a caça à vadiagem, sem deixar de tirar do anonimato que o artigo que ora se apresenta é imensamente tributário das reflexões de Michel Foucault. Menos conceitualmente, trata-se de um esforço procedimental presente nos trabalhos investigativos de Foucault que nos ajudará a levar a cabo esta empreitada analítica. A noção central que guiará nossos passos metodológicos é a de problematização (FOUCAULT, 2010), entendida aqui como o intervalo entre consensos ou, se quisermos, como o momento histórico privilegiado em que determinada vontade de saber (a própria ideia de vontade implica que esse saber ainda não imperara insofismável) atracou-se com outras, disputando as razões pelas quais algo deveria ser diferente do que era. Tudo se passa como se as sucessivas problematizações históricas escancarassem o período preciso em que as autoridades se assumem abertamente entre a ignorância total e a onisciência absoluta. Ou, ainda, a problematização é o momento histórico em que acompanhamos a passagem do dever ser ao ser; o momento, em suma, no qual se pode analisar com maior nitidez o nascimento de uma gramática normativa e performativa de certo aspecto da realidade social, na medida em que essa gramática se ajustava em formação, em vias de formular seus princípios basilares e constitutivos.

Além disso, da caixa de ferramenta de Michel Foucault, será igualmente importante a mobilização do conceito de biopoder (FOUCAULT, 1997), o qual foi cunhado por Michel Foucault para abrir um espaço de análise que buscasse descrever o modo pelo qual certas práticas sociais são governadas por noções que visam a consecução de objetivos políticos específicos. Ou seja, se as problematizações históricas indicam o caldeirão discursivo no interior do qual certas práticas puderam ser elaboradas. Assim, a noção de biopoder permite pensar o modo 
como essas mesmas práticas foram utilizadas estrategicamente, em razão de objetos políticos que hoje raramente se mostram a céu aberto.

\section{O DENUNCISMO COMO CONDIÇÃO DE POSSIBILIDADE DE UMA PE- DAGOGIA DO OLHAR}

Ao menos desde finais do século XVIII, as assimétricas conversações entre governantes e governados costumavam ser orientadas, em larga medida, pelos discursos laudatórios, como quando os súditos escreviam ao rei à cata de benefícios ou socorros. Por exemplo, José Bonifácio defendia com dentes e unhas o "direito sagrado de ir aos pés do trono representar seus males" (CALDEIRA, 2002, p.150). Assim, a 6 de março de 1883, um tal Francisco, natural do Açores, professor público de instrução primária, ao escrever ao rei com o fito de endereçarlhe uma rogativa, que extraía sua força e validade do solo da vontade daquele que rogava "a sinceridade do meu pedido...", sabia que, naquela situação em que a lisonja era o epicentro da argumentação, sua mise-en-scène verbal nada tinha quer ver com a formulação de um discurso com pretensões de objetividade ou mesmo de verdade, pois o fundamental era reforçar, por via da verbalização, o excelso e fulgurante poder do soberano. Pari passu aos rogos destinados ao soberano, os súditos também conheciam um outro ato de fala que os fraternizava a uma autoridade não menos consagrada, a saber, a religiosa. Claro, estamos falando da confissão. Tudo isso já foi fulgurantemente estudado por diversos autores, dentre eles, Foucault (FOUCAULT, 1988).

Ora, a esse quadro histórico sucede um contexto social no qual se incursionarão os súditos em um sistema de sincronização entre governantes e governados, fiado sobremaneira pela figura da denúncia, como se os próprios sujeitos fossem convertidos em portadores de um vetor de força punitiva à paisana; vetor este que não poderia funcionar sem as problematizações em torno das qualidades éticas do modo de ser do júri e das testemunhas. Se os indivíduos lisonjeavam como meio de tornarem-se íntimos dos poderosos, aproximando-se dos mesmos pela denúncia do outro, ao menos conheciam bem os riscos que corriam; dificilmente o mesmo se passava com a prática da denúncia, pois estes, por norma, imaginavam-se contrários aos poderes. E, no entanto, tentaremos mostrar como somente o "olho" de governado foi pensado para ser regido pela égide da denúncia, nunca o do governante. Ontem como hoje, olho vigilante de governante não denuncia; observa, e o faz para produzir saber, intervir etc.

Ora, se o médico do XIX aspirava a ser o estadista do futuro (REVISTA BRAZIL-MÉDICO, 1901), certamente ele não o faria sem um ferrenho combate aos poderes silenciosos da latência e seus males assintomáticos. Como vimos, a eleição do tema da latência decorreu de o medo da falsidade, entendida, aqui, no sentido de haver um elemento que desestabilizaria a ordem por meio da produção da aparência de ordem, servindo como argamassa da rotina de uma série de esferas sociais. O tópico do risco epidêmico envolvendo a "falsa" saúde coexistiu com o do risco da epidêmico da aparente estabilidade social. Assim, não faltam registros na polícia de São Paulo que alertassem as autoridades para o perigo de que as revoltas ocorridas em 1882 não estivessem arrefecidas, mas apenas mantidas latentes (MACHADO, 2010), o que também assumia a feição do provável na equivocada presunção de as sociedades secretas terem sido banidas do real ou, ainda, na errônea inferência de o conluio entre os escravos ter sido completamente devastado.

Ora, quem quer que se volte para o passado e se depare com uma massa de discursos a

PRACS: Revista Eletrônica de Humanidades do Curso de Ciências Sociais da UNIFAP https://periodicos.unifap.br/index.php/pracs ISSN 1984-4352 Macapá, v. 12, n. 1, p. 77-92, jan./jun. 2019 
respeito de uma contínua ameaça à fragilidade dos laços sociais, provavelmente imaginará que a resposta estatal ante um quadro social tão tenebroso não poderia ter sido outra senão o aumento de suas forças policiais e de vigilância. Como é evidente, a polícia, em todas as acepções do termo, jamais deixou de ser acionada. No entanto, também é verdadeiro que o policiamento preventivo dos distúrbios assintomáticos jamais funcionaria sem a denúncia feita pelos diletos cidadãos comuns, especialmente em situações cujo perigo se conservava de modo latente, como se a permanente suspeita por parte dos agentes do Estado de haver inúmeras realidades perigosas encobertas só tivesse sido possível de serem sondadas e sedadas por meio da democratização de uma prática de liberdade que conhecemos tão bem: a da denúncia. Em 1884, a Sociedade Médica de Lisboa defendia a imperiosa necessidade de: “Obrigar, por todos os meios moraes e legaes, os vizinhos relapsos a que procedam a beneficiação dos esgotos de suas casas e vigiar que tais beneficiações não sejam ilusórias" (SOCIEDADE DAS SCIENCIAS MÉDICAS DE LISBOA, 1884, p.10).

Decididamente mais importante do que afastar e isolar gripentos, muito mais eficiente do que adotar atitudes sectárias de qualquer espécie, essas autoridades, naqueles dias do XIX, forjaram um quadrante de conversações cujas circulação e internalização conduziram a uma maior coincidência entre os interesses do Estado e as inquietudes individuais. Do ponto de vista genealógico, a saúde não era apenas um "espaço de socialização" (EDLER, 2006, p.28), mas, acima de tudo, o pivô insuperável entre a ética individual e as expectativas do Estado. Como bem sabiam as autoridades, não fosse pela denúncia, a notificação obrigatória dificilmente seria cumprida pelo grosso da população. Estas e outras medidas profiláticas contracenariam com forte contradança, por parte de indivíduos rebeldes, convictos de que, por exemplo, o problema do acúmulo excrementício dizia respeito apenas à sacralidade dos arbítrios da higiene privada (SILVA, 2014). Ora, a fim de poder intervir sobre a esfera privada, essa esfera que se esconde e que, mesmo sem saber, esconde a latência dentro desse esconderijo, cumpria instaurar um modo de socialização do olhar, tornando, enfim, o privado acessível ao escrutínio público.

A noção de denúncia não foi forjada pelos médicos nem pela polícia do século XIX, ambos irrequietos com o combate de males que deviam e podiam ser amortecidos antes da sua efetivação no real. A prática da denúncia como modalidade privilegiada de exercício da liberdade popular vinha de longa data. Antes de ser um direito, o ato de denunciar foi um dever vigente no século XVIII, na medida em que todo cidadão era "obrigado a denunciar ao juiz os delictos públicos, que atacarem a ordem social” (FREIRE, 1786, p.121). A agenda de denunciar pertencia também aos aparelhos não estatais. Assim, no Manual dos Inquisidores, redigido em 1578, lê-se que aqueles não denunciassem uma heresia, teriam o triste fim de sucumbir à condição de sujeitos ao castigo da excomunhão (NICOLAU, 1972).

No mesmo Manual, inquisidores esclareciam os três caminhos ofertados para abrir um processo: acusação, inquisição e denúncia. Pois bem, diferiam esses três tipos de reclamação aos representantes do poder espiritual quanto às provas concretas para a denúncia. Se a sobredita acusação exigia o respaldo de provas: "No caso de os depoimentos não carrearem senão meias provas contra o Acusado, deve então o Inquisidor aconselhar o Delator a que, na sua queixa, mude a palavra acusação para a palavra denúncia" (NICOLAU, 1972, p.13).

A primeira tendência do leitor contemporâneo seria a de enxergar nessas linhas a prova cabal de que a Inquisição exercia seu poder condenando sem provas pessoas inocentes à fogueira, ainda mais se não nos esquecermos de que a denúncia feita pela testemunha de boa 
reputação exigia apenas ter "ouvido dizer a fulano ou a sicrano que o Acusado é hereje" (NICOLAU, 1972, p.17). Essa conclusão só é verdadeira em parte. A ausência de provas não constituía erro para as autoridades eclesiástico-jurídicas da época. Não figurava exagero incessante mais ou menos tolerado. Era uma modalidade de poder que cumpria uma função específica no interior das dinâmicas dos tribunais da Santa Inquisição. Supremamente mais do que apagar da face da terra os suspeitos de heresia, a função que a prática da denúncia possuía era a de registrar o nome de cada um dos indivíduos que, uma vez denunciados, tinham tornavamse suspeitos de heresia, pois "Se qualquer acusação intentada era completamente desprovida de verdade, não é obrigada o inquisidor a apagá-la do seu livro, pois aquele que não se descobre em certa altura pode vir a descobrir-se noutra" (NICOLAU, 1972, p.15).

A problematização histórica em torno da prática da denúncia realizada pela população em geral remete, em primeira e última instância, à discussão em torno dos poderes que as autoridades estatais e não estatais dispunham-se a delegar aos vassalos e aos cidadãos, a fim de que esses mesmos poderes pudessem até mesmo chancelar e fortalecer a relação entre os poderes formais, informais e não formais, que alimentavam esta ou aquela forma de organização social desde o século XVIII; problematização que, aliás, alinhava-se às reflexões de um dos mais insigne jurista português, Mello Freire, para quem uma das tarefas urgentes do ordenamento jurídico consistia em demarcar quais os poderes pertenciam ao Estado, quais ao corpo eclesiástico e quais aos leigos (FREIRE, 1789). A prática da denúncia representou uma das maneiras que o Estado moderno encontrou para comissionar o uso de uma forma de autoridade montada e elaborada para fortalecer a si próprio; fortalecimento intensificado a partir da ausência da sombra dos comandos por parte do Estado, pois, era sabido pelas autoridades que recrutassem um operário como um soldado irritariam seu espírito, predispondo-o para a "emigração” (LARANJO, 1871, p.115), exigindo passar-se do "despostismo para a liberdade” (LARANJO, 1871, p.116).

Faz sentido dizer que, desde Bonifácio e seu projeto de divisão dos poderes feito por quatro órgãos (Câmara, Senado, Sindicato e Arcontado), o Brasil desconhece a oposição entre a delegação de poderes e o crescimento da força do Estado. Tampouco se poderá esquecer que, desde o século XVIII, um mesmo declive invencível parecia orientar tal exercício delegatório: democratizar o julgamento sobre um objeto, sem delegar, no entanto, os meios de produzi-lo.

Estou capacitado de que os grandes projetos devem ser concebidos e executados por um só homem, e examinados por muitos; de outro modo desvairam as opiniões, nascem disputadas e rivalidades; e vem a faltar aquele centro comum de força e de unidade, que tão necessário é em tudo, e mormente em objetos de suma importância (CALDEIRA, 2002, p.102).

É mais difícil conceder à hipótese de que, desde antes da fundação de Piratininga, a liberdade (em geral) e o abuso da liberdade (em particular) tenham sido pensados para aferir julgamentos. Sintetizando: não é possível compreendermos a prática da denúncia se não o inscrevermos em um sistema determinado de poder-dever, haja vista não estarmos diante de uma modalidade de poder facultativa, e sim de um exercício de poder decorrente de uma injunção e de comandos cotidianamente formulados e prescritos por certas autoridades. Não obstante, tal dever venha a ser reinterpretado como um direito inalienável do cidadão, integrado ele a turma dos de bem ou a massa dos oprimidos. Na verdade, todo um complexo jogo de confisco e de delegação de poder estava aí em prática. Por isso, não é desejável nem possível compreender a atribuição aos indivíduos do poder de denunciar sem levar em conta o confisco do

PRACS: Revista Eletrônica de Humanidades do Curso de Ciências Sociais da UNIFAP https://periodicos.unifap.br/index.php/pracs ISSN 1984-4352 Macapá, v. 12, n. 1, p. 77-92, jan./jun. 2019 
poder de portar arma de fogo, só para citarmos um exemplo.

Em Portugal, em meados de 1719, o porte de armas já era vetado, e essa admoestação tinha de fazer-se conhecida por todos, o que levava um autor como Antônio Vanguerve a endereçar sua obra tanto aos doutos quanto aos curiosos, pois seu modo de intelecção jurídica deveria "ser entendido de todos" (CABRAL, 1729, p.3). Novidade histórica? Em larga medida, sim. Por mais que o Estado convocasse os vassalos às armas em tempos de guerra contra outras nações, incitando o povo a se armar (Gameiro, 1808), por mais que uma longa tradição desse ao rei a chance de desembaraçar de toda pena ou multa as pessoas amarrotadas em torno de suas armas para defenderem suas casas (FREIRE, 1786), por mais que alguns juízes persistissem em conceder ao leigo "licença para prender alguém”" (FERREIRA, 1730, p.42), a imposição do desarmamento foi, sem sombra de dúvida, o chamamento dominante entre os Estados modernos. Em pouco tempo, nenhum vassalo, nem o condenado à morte, nem o fugido da prisão ou do suplício, podia "ser morto por qualquer pessoa do povo" (FREIRE, 1786, p.6). Deste modo, o poder de punir com as próprias mãos ou com as próprias armas, cede espaço para o exercício do poder discursivo, por meio da denúncia.

Com efeito, do ponto de vista das turbulências internas, o uso de armas, se acreditarmos nos inúmeros editais que se batiam inutilmente para dar cabo da prática do duelo, os vulgos "Dezafios" (CABRAL, 1729, p.157), tinha de deixar de compor o "ramerrame" de parte significativa dos vassalos do século XVII. Para o pesar dos duelantes, a 23 de julho de 1678, já ia asseverado:

Hey por bem que nenhuma pessoa de qualquer qualidade, estado \& condição que seja possa trazer consigo faca, não só das prohibidas da dita ley, a que chamam de ponta de diamante, fovela ou folha de oliveira, mas de qualquer forma que seja fabricada, se com a ponta della se puder fazer ferida penetrante (CABRAL, 1729, p.217).

Disso tudo, mais notável é perceber como a operacionalização do rearranjo na distribuição dos poderes não ocorria de cima para baixo. Atulhadamente ao contrário. O confisco do poder de portar armas dependia da discricionaridade do Estado para dar aos indivíduos o poder de confiscar parcelas do poder. Subtrair certo poder dos indivíduos supunha, daqueles que o saqueassem, por sua vez, o dever de indenizá-los. Ao arrancar dos súditos sua defesa em posse de armas, o Estado, em compensação, provia-os a todos do poder de fiscalizar, declarando o direito a "denunciar em segredo" as pessoas que trouxessem consigo "as ditas facas \& mais armas" (CABRAL, 1729, p.228), exceto à noite, quando se permitia o porte do arcabuz, da espingarda, da pistola e do pistolete (FREIRE, 1789). Por via da apropriação da denúncia pelos súditos, tornava-se aceitável que, à parte os castigos leves impostos pelos pais aos filhos, ou às mulheres, ou ainda pelos senhores aos escravos, o Estado monopolizaria, dali em diante, o uso da força. Assim, a denúncia foi a maneira pela qual o Estado moderno encontrou insumos entre a população para esvaziar outros poderes pertencentes a essa mesma população. Quer dizer, a prática da denúncia configura o exemplo mais claro de como a população foi privada de uma modalidade de poder pela ativação de um outro poder de quem ela recebeu, paulatinamente, indenização por meio do poder de fiscalizar e, enfim, denunciar.

Mais do que um mecanismo para apassivar a população em geral, importa notar que a especificidade da denúncia preventiva radicava na sua destreza em fazer coincidir o poder da denúncia pessoal com as expectativas das autoridades ausentes. Se o Estado era visto como "uma pequena parte da sociedade" (LEITÃO, 1889, p.7), era preciso que as outras partes

PRACS: Revista Eletrônica de Humanidades do Curso de Ciências Sociais da UNIFAP https://periodicos.unifap.br/index.php/pracs ISSN 1984-4352 Macapá, v. 12, n. 1, p. 77-92, jan./jun. 2019 
estivessem alinhadas e concordes com ela. Reparemos: em finais do século XIX, as autoridades médicas que clamavam pelo aumento do corpo dos desinfetadores eram as mesmas que solicitavam aos moradores desfecharem "queixa” (REVISTA BRAZIL-MÉDICO, 1896), sobretudo quando sua maloca tivesse sido esquecida pelos higienistas. A denúncia pessoal orientavase a apontar carências no atendimento, a fim de alertar para pontos ainda cegos, validando-se, portanto, na medida em que aguçava os programas pré-estabelecidos pelos poderes estatais. Em suma, o denunciante frente ao poder formal cobrava conforme as falhas e deficiências de um projeto previamente elaborado por este.

Nesse sentido, não custa lembrar, já no início do século XX, o gesto de discar 1092 era um poder disponibilizado para que qualquer um da população fornecesse denúncias acerca de casos de doentes ou de suspeitos de estarem doentes (BERTUCCI, 2004). Falar aos poderes, inclusive denunciando falhas dos próprios poderes, representava uma via de enfrentamento contra os poderes; via antecipadamente arquitetada pelos próprios poderes, o que nos permite abraçar a tese, valendo-nos de uma ideia de um teórico contemporâneo, de que a distribuição dos poderes ali em causa consistia em astutamente "trocar a conspiração pela expressão" (GOFFMAN, 1961, p.97). A construção e a mobilização da prática da denúncia influíam, sobretudo, dois efeitos práticos: esvaziar os poderes que o Estado pretendia alijar, para reforçar os poderes do próprio Estado. A bem dizer, tal engrenagem de poder ostentava e ostenta um nome: tutela. Ora, se o poder de denunciar, entendido como meio privilegiado de ativar a tutela sobre si ou sobre o outro, era tão caro ao Estado, isso decorria, entre outros fatores, de ele funcionar, em certo sentido, a despeito da vontade dos particulares diretamente envolvidos em alguma situação privada conflituosa, cuja mediação deveria estatizar essa queda de braço.

A pessoa ofendida pode, quando sozinha com quem a ofende, agir de maneira tolerante e conciliadora, preferindo a paz à justiça. No entanto, a presença de uma testemunha parece acrescentar algo às consequências da ofensa. Afinal, nesse caso, está fora do poder do ofendido e de quem ofende esquecer, apagar ou suprimir o que aconteceu; a ofensa tornou-se um fato social público (GOFFMAN, 1961, p.120).

Pretendemos enfatizar a introdução do denunciante no seio do cotidiano como catapulta de boa parte dos processos de ganho de autonomia das intervenções estatais com pretensões de acessar e modelar um número significativo de atividades privadas, as quais, de outro modo, sequer seriam conhecidas. O primeiro efeito jurídico da denúncia consistia em subtrair o poder de decisão a respeito do cabimento do ato de julgar e punir da alçada do privado, passandoos imediatamente para os poderes públicos. A presença do denunciante em meio aos pés de guerra cotidianos esvazia dos indivíduos particulares o poder de decisão sobre serem ou não tutelados pelo Estado. Isso tudo será fundamental, como veremos, para o nascimento de certa experiência cinematográfica, no advento do cineclubismo e do projeto educativo que lhe era coextensivo e que denominamos, em outra ocasião (ZANONI, 2015), por meio da sindicalização do olhar.

Convenhamos, desempenhar o elo entre o Estado e as esferas particulares não é, de todo em todo, um poder de menor monta, ainda que assim o pareça do ponto de vista da experiência individual, como quando, no sofá da própria casa alguém decide engatar o dedo em um disque-denúncia. Com a ascensão da Modernidade, os espaços privados, como é sabido, não serão facilmente acessíveis, especialmente por representantes diretamente encadeados ao Estado (ROSE, 1999). A possibilidade de conhecer e intervir no lar dos cidadãos, bem como em

PRACS: Revista Eletrônica de Humanidades do Curso de Ciências Sociais da UNIFAP https://periodicos.unifap.br/index.php/pracs ISSN 1984-4352 Macapá, v. 12, n. 1, p. 77-92, jan./jun. 2019 
outras esferas entendidas como de foro íntimo, não se fará, nem jurídica nem eticamente, sem mil perigos para os protocolos de legitimação estatais. Nesse sentido, já no tempo de Pombal, as visitas as casas só podiam ser disparadas, ao menos em tese, após alguma denúncia, isto é, depois que o cidadão comum já tivesse sido transformado em suspeito (AMENO, 1784, p.138).

Ora, se juntarmos o que foi dito a respeito da latência à questão da inviolabilidade do espaço privado, a importância da prática da denúncia ganha ainda mais relevância. A fim de fazerem decolar seus projetos, as autoridades estatais, para serem consequentes, tinham de enfrentar duas formas de tapume responsáveis por toldar a visibilidade dos males biológicos que os dardejavam: o espaço privado que abrigava indivíduos e, conscientemente ou não, abrigava os males dormentes. A questão do acesso ao privado gerava contendas não apenas entre médicos e pacientes, entre juristas e criminosos, mas também entre médicos e juristas, sendo esse imbróglio um dos raros momentos em que estes e aqueles, apesar de sua comum noblesse oblige, não assentavam acordo. "Nada legitima, diz textualmente outro júris-perito, a remoção do corpo do seu domicilio em vida para o deposito publico dos mortos, sinão nos casos excepcionaes de autópsia por moléstia infeciosa ou crime (REVISTA BRAZIL-MÉDICO, 1901).

Quer dizer, sem a presença de um denunciante garantindo que o mal estava secretamente inscrito neste ou naquele corpo, morador desta ou daquela casa, ou neste e naquele comércio, ou ainda nesta e naquela embarcação de homens e mercadorias, a liberdade interventiva dos médicos continuaria a ser incluída na conta das medidas de "exceção", tidas como violentas e arbitrárias tanto pelos comerciantes quanto pelo público em geral. Sem o denunciante para alimentar esse medo arrepiante e interventivo, a atuação médica em esferas privadas poluiriao como um pesado tributo.

Eis, portanto, a intrincada e delicada equação entre, de um lado, observar o dever preventivo de intervir e resguardar os bens da comunidade e, de outro, assegurar o dever de não o fazer. Se a prática da denúncia era isso, esse instrumento de governo tão fundamental para o bom funcionamento das engrenagens do Estado, este não deixaria de acionar uma legião de iniciativas que o inscrevessem e o enraizassem no cotidiano; iniciativas cuja recorrência tornálo-iam um dado natural na paisagem social, a ponto de quase não haver, ao longo dos séculos XIX e XX, um manicômio e uma prisão cujos internos e condenados não tenham um denunciante como causa do seu destino inglório (GOFFMAN, 1961).

Das iniciativas, a principal jazia no esforço de extrair a impressão de que a denúncia não era requisitada pelas autoridades; ela nada mais era do que uma demanda dos próprios cidadãos, que se iam familiarizando com o mantra de que aperfeiçoar a si e a cidade ou o futuro implicava apurar a conduta alheia e, se fosse o caso, de denunciá-la. Eram coisas do passado homens na clausura de si, encapsulados no mau hábito de serem "reflexivos só para o seu egoísmo" (CALDEIRA, 2002, p.254). Se a denúncia não partisse dos próprios cidadãos, se não fosse fortalecida sob a forma de uma demanda formulada em primeira pessoa, tudo isso afrouxaria a credencial ética das autoridades preventivas, convertendo-se em fonte de temor para o povo. De preventivas, as autoridades passariam a ser encaradas como agressivas.

Sem maiores comentários, os médicos bem sabiam que a remoção "goela abaixo" de suspeitos acabaria inspirando no povo "atitude hostil", tornando-os temidos e evitados, quando mais útil lhes seria que fossem requisitados e solicitados. Por isso, cabia à medicina preventiva a tarefa de criar o vocabulário mobilizado pelos denunciadores, mas nunca a de tomar para si seu papel:

PRACS: Revista Eletrônica de Humanidades do Curso de Ciências Sociais da UNIFAP https://periodicos.unifap.br/index.php/pracs ISSN 1984-4352 Macapá, v. 12, n. 1, p. 77-92, jan./jun. 2019 
6. - Vendo nos médicos os denunciadores forçados da sua situação, o povo teme e evita também estes, de modo que, precisamente nas épocas epidêmicas (...) é quando os doentes mais escapam á sua vigilância, porque, nas condições em que se faz o cumprimento da lei, longe de ver a sua intervenção como um auxilio e um socorro, o povo a recebe como uma violência e uma agressão (REVISTA BRAZIL-MÉDICO, 1901).

Como era costume dizer-se à altura, os médicos "preventivistas", sem esses cuidados, correriam o risco de ser aparentados pelo povo a meros caçadores de casos suspeitos, como autoridades caracterizadas por entregar inocentes que não se despedaçavam em doenças visíveis ao descalabro da sequestração oficial. Para que a prevenção surtisse seus efeitos esperados, o melhor remédio residia na destreza em recodificar, via educação, as imposições médico-estatais em benefícios espontaneamente procurados. Uma vez educado, o cidadão não tardaria a reclamar a sua execução, leia-se a execução dos programas prévios de governo. Vale insistir: as autoridades empenhadas na montagem do dispositivo da denúncia não podiam fazer uso dela:

9. - Nas condições actuaes, quasi sempre o médico torna-se mero denunciador ao poder publico do doente que encontrar, para que venha apossar-se delle; e isso é um mal imenso, porque o povo, para evitar esse procedimento, não chama o medico e priva-se do seu auxilio quando mais o devia procurar (REVISTA BRAZIL-MÉDICO, 1901).

Antes do século XIX, os estados brasileiro e português já conheciam a figura do inimigo interno, mas não exatamente a do inimigo íntimo. Conheciam os Inconfidentes ao Estado (GAMEIRO, 1808), indivíduos ocultos em locais secretos e decididos a sepultar o Estado, mas não o cidadão ordinário e despolitizado que, inconscientemente, punha em risco biológico o bem-estar da nação. À parte a Guerra do Paraguai, o mito de um povo cordial avesso aos grandes litígios internacionais só foi historicamente possível porque a política brasileira exercitada até então, violenta até o último fio de cabelo, sempre privilegiou o massacre de seus inimigos internos, privilegiando, por extensão, a dimensão "policialesca" em prejuízo de seus aparatos militares.

Pois bem, para atiçar a sanha da denúncia, era preciso que o povo suspeitasse não apenas dos encontros noturnos possíveis apenas nas casas de pessoas escusas, mas também que desconfiasse do marido, do filho, do vizinho, do colega de profissão e de todos aqueles que compusessem o círculo da intimidade. Em regime de latência, somente um pai ou um esposo podiam atestar a bizarrice dos hábitos secretos de seu filho ou sua esposa.

O perigo de infecção por meio da poeira de gotticulas de escarro é evidentemente maior para aquelles que convivem com tísicos que tossem e lançam borrifos de saliva, e para os que são obrigados a demorada permanência junto dos mesmos; marido e mulher, pães e filhos, operários, empregados de escriptorio, estudantes etc, quando em cada caso, algum dentre elles for tuberculoso de facto e desta natureza a maior parte das observações de contagio (BRAZILMÉDICO, 1902).

A educação ganhava, então, a dianteira. A fim de o Estado encarnar um "anjo tutelar" (CALDEIRA, 2002, p.113), nada melhor do que acionar os mecanismos educativos formais e informais para incutir nas crianças a equivalência entre as "batatas e os homens"; fundamental 
era ensinar-lhes que os objetos cotidianos podiam ocultar moléstias:

Para attingir com segurança ao fim desejado, é preciso ainda fazer previamente a educação sanitária do povo, ensinar a hygiene (...). Ensina-se a creança que existem moléstias da vinha e da batata; porque não se lhe ha de ensinar que existem igualmente moléstias do homem, cujos perigos deve conhecer, assim como o modo de propogação, para saber se defender (REVISTA BRAZIL-MÉDICO, 1901)?

Educação como meio de disseminar menos as letras e os cálculos, e mais o gosto e o hábito da denúncia? Exatamente: "Neste, como em todos os outros casos da vida social, não é multiplicando o vigor penal que se evitam os delictos, mas sim combatendo-lhes as causas, para que elles não se possam commetter” (REVISTA BRAZIL-MÉDICO, 1901).

A partir de 1945, a prática da denúncia entrará de corpo e alma nos protocolos educativos dos cineclubistas brasileiros, especialmente pelas mãos de Humberto Didonet, inequivocamente um dos mais destacados cineclubistas brasileiros, responsável, em maior ou menor grau, pela formação de toda uma geração de importantes críticos de cinema, dos quais Jean-Claude Bernardet se tornaria o mais famoso. Ora, como veremos, a prática da denúncia cineclubista, à moda da prática da denúncia acima descrita, exercer-se-ia em fazer do não poder o princípio de mobilização e construção de um hiperpoder, como se a impotência suposta na vitimização (biológica ou ética) fosse o trampolim para a construção de uma quase onipotência prometida para um futuro no qual as relações de poder seriam, enfim, simétricas.

\section{A PEDAGOGIA DO OLHAR}

Para os pedagogos do olhar brasileiros e portugueses que atualizavam o modelo de compreensão da imagem forjado pelo Direito e pela medicina ao longo dos séculos XVIII e XIX, o modo de problematizar a imagem cinematográfica seguia as mesmas orientações das imagens que os poderes identificavam existir na cabeça da prostituta sifilítica, do rábico ou do líder anarquista vadio, pois as imagens em movimento, à semelhança daquelas exultadas pelas subjetividades das referidas categorias sociais, agiam como instâncias cuja força normativa suplantava a realidade, forjando comportamentos orientados mais pela imagem indiretamente transmitida do que pelo acesso direto ao real.

A gigantesca popularidade do cinema fazia com que as imagens fílmicas habitassem uma multiplicidade de consciências, eis o que não podemos perder de vista. Por isso, como integrantes de multidões, os frequentadores de cinema, se não se contorcessem aos protocolos de pedagogia do olhar, tornar-se-iam perigosos, e isso por internalizarem imagens que induziam à adoção de um modo de vida perigoso. Assistir a um filme não era ato ilegal, porém o simples contato prolongado com esta ou aquela imagem em movimento produziria indivíduos cujos estados internos seriam, eles sim, possivelmente contrários à lei. Tal como a briguenta multidão mambembe, o cinema fincava-se, pois, como o meio social em que se fabricavam interioridades reféns de imagens irreais, as quais levariam ao aparecimento de comportamentos antissociais, predadores, propensos ao crime e outras formas de ilegalidade.

No fundo, pela ótica das pedagogias cineclubistas, na medida em que o cinema não solicitava o trabalho da inteligência por sua natureza imagética, os saberes dos mediadores tinham de fazer-se ouvir, a fim de despertar a razão adormecida por esse peculiar embalo sinestésico, no qual os espectadores tinham sido envolvidos como em um sonho em que se é privado da 
faculdade da razão. Assim, os conceitos disponibilizados pelos cineclubes eram, nesse sentido, uma maneira de prevenir o espectador contra os temerários caprichos da sensação. Era a isso que se chamava senso crítico, a saber, a possibilidade de o espectador esconjurar a identificação do sonho com a realidade e de frear, desse modo, a tendência a imitar aquilo a que assistia. Ontem como hoje, o sonho marca o momento em que o sujeito que representa dado objeto ou dada situação desvirtua-se a si e à situação em que está simultaneamente representando um mundo e descontextualizando-se do mundo de onde rebenta a distorção.

Mas nada disso seria realizável sem o que designamos sindicalização do gosto. Ora, essa noção não nos deve fazer crer que tal estratégia de regulação do campo cinematográfico fosse aplicada aos depauperados e a todos os que não gozavam de um acesso regular ao cinema. Ao contrário, cabia à elite do cinema submeter seu gosto pessoal ao processo de sindicalização e, então, converter-se em um espectador-mutirante. Assim, após sucessivas estratégias argumentativas de demonstração da necessidade incontornável de o espectador educado advogar em favor do bom cinema, eis a súmula conclusiva de Didonet, especialmente endereçada ao espectador cineclubista: "Fans de Cinema de Todo o Mundo", "UNI-VOS", e uni-vos sobretudo em torno da "FRENTE ÚNICA PELO BOM FILME" (DIDONET, 1959, p.58).

Por meio do projeto de sindicalização do gosto, Didonet apostava na possibilidade éticopolítica da união dos consumidores cultos de cinema como princípio de pressão para soprar os rumos da indústria cinematográfica, espelhando, assim, as diretivas do Papa Pio XI, para quem a Igreja Católica teria de aprovisionar o "incentivo de associações” (DIDONET, 1963, p.26), as do apostolado leigo, o único que lograria condições de garantir um tipo de condução dos espectadores pautada na inculcação da vontade de - a respeito dos filmes - "Ver, Julgar e Agir” (DIDONET, 1963, p.26), tripé montado para combater, principalmente, a poderosíssima indústria de cinema estadunidense ou, ainda mais precisamente, para combater o fato de aquela indústria imagética forjar e reluzir imagens em movimento prenhes de males latentes, sejam eles físicos, comportamentais, ideológicos, entre tantos outros. Como estamos a ver, a reciprocidade entre os membros, ou seja, a suposição de uma certa igualdade das inteligências, não tinha que ver com a igual vontade de produzir narrativas fílmicas; a luta por uma assimetria entre os receptores das imagens em movimento havia sido inteiramente canalizada pela tarefa da sindicalização do olhar. Se todos os poderes operam pelo confinamento, nem todo o confinamento opera pela repressão. No caso da sindicalização, o confinamento resulta da idealização, da certeza de que a montagem de um grupo específico dotado do poder de julgar as obras fílmicas catapultará as experiências cinematográficas positivas, aniquilando as negativas. Diferentemente da figura dos "medianeiros" (PAIVA, 1843, p.82), entendidos como os "amigos dos poderes contendores” (PAIVA, 1843, p.83), especialmente em épocas de guerra, a figura dos mediadores, na arena da cultura, seria tanto mais eficiente quanto mais tomasse partido. Em breve parêntese, vale conhecer o exemplo seguinte: "medianeiros devem adoçar os ressentimentos, e predispor os espíritos para a paz (...) porque são conciliadores, e não juízes" (PAIVA, 1843, p.83). Os espectadores conspirariam para o mesmo esforço de redirecionamento do cinema, contanto que internalizassem os instrumentos de poder-saber ofertados pelos cineclubes, pois somente o gosto sindicalizado via-se habilitado a corretamente eleger o que ver e como ver:

Para este estado de coisas só há uma solução: exigir da produção um cinema renovado, e isto só os espectadores o podem fazer, começando por combater os filmes de má qualidade. Mas só 
um público capaz de escolher tem possibilidade de exigir (BOLETIM CINECLUBE DE BEJA, 1958).

A sindicalização do gosto, bem como a legitimação das escolhas que dela decorriam, só se imporia como reviravolta histórica fundamental no modo de constituição da experiência cinematográfica se contasse com os mecanismos suscitadores da adesão interna de cada um dos espectadores. Do contrário, o tiro esparramar-se-ia pela culatra. Se pressionados diretamente pela lei, os espectadores, em vez de concentrar o julgamento dos seus martelos em prol do filme, levantar-se-iam em um motim contra este ou qualquer outro filme prescrito pelo Estado. Como fazia questão de frisar Lúcio Cardoso: "Como todos devem estar lembrados, os primeiros shorts obrigatórios, causaram verdadeiros escândalos na platéia. Não estivemos longe de assistir a um motim de espectadores" (ARQUIVO CINEMATECA BRASILEIRA, 1941).

Descontadas iniciativas pontuais e episódicas de intervenção direta sobre a produção, sobressaiu a estruturação da conduta do espectador como espectador, sem a preocupação de tentar encaminhá-lo ao polo da produção. Antes ou depois da exibição dos filmes, o mediador cineclubista intervinha e ensinava o espectador a julgar aquilo que viu. Julgamento do qual se esperava, como estamos vendo, a inversão de poder entre o espectador e a narrativa fílmica; inversão visível pela instalação de tribunais estéticos, ao mesmo golpe individuais e coletivos, nos quais os espectadores, armados com o poder de julgar, definiriam para si e os outros a "assistibilidade" do filme em arbítrio. Do mesmo modo que vigoravam os sindicatos dos metalúrgicos e dos petroleiros, a aposta central dos dirigentes da cultura cinematográfica era a de que seria possível e desejável construir um sindicato de espectadores composto por intelectuais. $\mathrm{Na}$ verdade, da parte de Didonet, era mais ou menos evidente:

Onde os intelectuais, os homens de cultura marcaram uma presença mais substancial, foi no campo não de produção ou exploração comercial, e sim no da interpretação, ou seja, no trabalho de apreciação dos filmes, depois de feitos e exibidos (DIDONET, 1959, p.47).

Era claro como água que o poder de interpretação, ponto por ponto, equivalia ao poder de julgar, de modo que o gesto de apreciar implicava escoltar ou desamparar os filmes. Se a missão dos cineclubes consistia em combater os males escondidos de maneira latente por sob as imagens em movimento, a hermenêutica no cinema não poderia ser senão um gesto médico, jurídico e policialesco.

Nessa redoma, o gesto de julgar era, portanto, decisivo para o futuro do cinema. Do número de laureadores do bom cinema ou de inimigos do mau cinema, dependia o maior ou menor promoção do cinema artístico. Só assim os espectadores teriam, enfim, seu direito fiscalizador assegurado. Interpretar e julgar, a fim de melhor fiscalizar, eis o pacote de medidas éticas que, uma vez internalizado pelos espectadores ditos conscientes, conservaria um tipo de controle eficiente e duradouro sobre o fluxo e o refluxo das salas de cinema, especialmente das salas comerciais. No dicionário de Didonet, esse pacote de atitudes para consigo, para com o outro e para com o cinema tinha um nome: "teologia pastoral" (DIDONET, 1959, p.47) certamente a plataforma de arranque para a criação de uma "elite” (DIDONET, 1959, p.50), de um grupo de espectadores aptos a julgar e influir sobre o gosto do grande público, de um tipo de olhar vanguardista endereçado aos filmes que, imunizado contra as seduções (latentes ou não) do cinema, introduziria nos afazeres fílmicos um modelo de reciprocidade que tornaria a indústria cultural cinematográfica tão dependente do gosto do espectador quanto este já se 
segredava dependente daquela.

\section{CONCLUSÃO}

Importa adiantar, a compulsão em direção ao ato de julgar obras cinematográficas não advém, sob nenhuma hipótese, de um qualquer sadismo secreto no coração de espectadores gregos e troianos. Muito ao contrário. O que esteve em jogo ao longo da presente argumentação foi a tentativa de explicitar que a reposição do julgamento como prática normal ante uma obra com pretensões estéticas resultou de a linguagem jurídica ter sido historicamente fornecida aos espectadores como solo natural aos interessados em formular um tipo de avaliação a respeito daquilo a que assistem, seja ela positiva ou negativa, seja ela pessoal ou institucional - por exemplo, não apenas os adjetivos que usamos para classificar um filme, mas também as premiações em festivais de cinema. A força que imaginamos inerente aos nossos diálogos com esta ou aquela obra foi concretamente imaginada por autoridades médicas e jurídicas que fizeram do julgamento o expediente maior, quando não o único, a ser empregado pelos sujeitos. Indubitavelmente, o julgamento sobre a validade dos filmes é um tipo de arbitragem cultural absolutamente consolidada na paisagem social da contemporaneidade.

Quais vozes, dentro de nós, convocam-nos para o ato de julgar? Certamente, vozes jurídicas, vozes médicas e outras vozes preventistas. Mas há mais: tais vozes tendem a ser quase que invariavelmente positivadas. Não nos sentimos carrascos ao julgar e condenar uma obra. Longe disso. Sentimo-nos, isto sim, cavaleiros engajados em uma cruzada pelo bem ético ou estético de um espectador, de um grupo ou, ainda, de toda uma nação. Como é mais ou menos sabido, para poder funcionar a contento, os espectadores julgadores não podem representar a si mesmos como representantes do aniquilamento de algo bom. Portanto, não seria equivocado se levantássemos a hipótese de que, nessa toada genealógica, o exercício do julgamento foi sendo constituído historicamente como um tipo de validação pessoal a que os sujeitos aspiram a fim de transformarem-se em espectadores melhores. Com efeito, ao enfatizarmos que o ato de julgar jaz no cerne do modo de ser dos espectadores, não estamos a dizer que isso é ruim, mas a tentar mostrar que essa prática social supõe um tipo específico de deslocamento de si tornado dominante: da posição de espectador à de julgador, mudança esta que vinculamos à prática da denúncia, pois a resolução das assimetrias entre a indústria cultural e os espectadores passaria por essa prática de liberdade de tipo jurisdicional em face dos comandos de Hollywood, como se o espectador-julgador quase se convertesse em coprodutor dos filmes por vir.

Portanto, o objetivo último desta investigação foi, em certo sentido, estabelecer nexos entre a posição do espectador e a possibilidade de ingresso na função de produtor de narrativas fílmicas, pois a maneira de assistir a um filme determina, em maior ou menor grau, a capacidade de poder vir a produzi-lo, já que todos os sistemas de governo supõem um tipo de trabalho típico dos poderes, isto é, um modo como certas práticas discursivas especializam-se e têm por meta o estabelecimento e a marcação de lugares sociais. O olhar da contemporaneidade não foi historicamente exercitado para criar a partir do encontro com o já criado. Ao contrário, ele encaminha-se no sentido de julgar o já criado, como se a tarefa do bom espectador residisse em proferir uma sentença sobre o que o universo fílmico deveria ser ou não ser. Não à toa, o lugar social construído para a formação do diretor que vamos admirar nunca é o mesmo construído para o espectador que vamos salvar. Tudo se passa como se o consumo

PRACS: Revista Eletrônica de Humanidades do Curso de Ciências Sociais da UNIFAP https://periodicos.unifap.br/index.php/pracs ISSN 1984-4352 Macapá, v. 12, n. 1, p. 77-92, jan./jun. 2019 
cultural de obras fílmicas fosse ativado pela lógica do engajamento e administrado pelo dispositivo do julgamento, que produz na arte aquilo que as relações de poderes produzem na escala social.

Não enquadrar a história do cinema no interior de nossas coordenadas atuais de cognição espectadora é um modo de tentar pensar uma agenda para o cinema que não faça do julgamento o teto último do nosso imaginário político, talvez uma das tarefas políticas mais urgentes para a reelaboração de uma nova ética diante do cinema. Certamente, abandonar o primado do julgamento não traria ao cinema uma nova manhã de festa, mas ofertaria aos sujeitos que habitam o presente a possibilidade de, quiçá, experimentar os desafios de um amanhecer enevoado, um amanhecer que não seria nem uma manhã de festa, isento de questionamentos, nem um horizonte marcado por um breu total.

\section{BIBLIOGRAFIA}

AMENO, Francisco Luiz. Elementos da policia geral de hum Estado. Lisboa: Officina de Francisco Luiz Ameno, 1784.

BENJAMIN, Walter. A obra de arte na era de sua reprodutibilidade técnica. Porto Alegre: Zouk Editora, 2012.

BERTUCCI, Liane Maria. Influenza, a medicina enferma. Campinas: Editora Unicamp, 2004.

Boletim Cineclube de Beja.

CABRAL, Antônio Vanguerve. Epílogo jurídico de vários casos cíveis e crimes concernentes ao especulativo e prático, controvertidos, disputados e decididos a mayor parte delles no Supremo Tribunal da Corte \& Casa da Supplicação com humas infignes anotações à ley novíssima da prohibição das facas $\&$ mais armas promulgadas em 4 de abril de 1719. Lisboa: Officina de Antônio Pedrozo Galram, 1729.

CALDEIRA, Jorge (Org.). José Bonifácio de Andrada e Silva. São Paulo: Editora 34, 2002. CORTÁZAR, Julio, Todos os fogos o fogo. Lisboa: Cavalo de fogo, 2011.

DIDI-HUBERMAN, Georges. O que vemos, o que nos olha. São Paulo: Editora 34, 2011. DIDONET, Humberto. Você sabe apreciar cinema? Rio Grande do Sul: Sesi, 1957.

. Promoção de bons filmes. Porto Alegre: Edições Paulinas, 1959.

Associativismo. São Paulo: Sesi, 1963.

EDLER, Flávio Coelho. Boticas e Pharmacias: uma história ilustrada da farmácia no Brasil. Rio de Janeiro: Casa da Palavra, 2006.

FERREIRA, Manoel Lopes. Prática criminal expedida na forma da praxe observada neste nosso Reino de Portugal e illustrada com muitas ordenações, leys extravagantes, regimentos e doutores. Lisoba: Officina Ferreiriana, 1730.

FREIRE, Pascoal José de Mello Freire. Código criminal intentado pela Rainha Dona Maria I. Lisboa: Simão Thaddeo Ferreira, 1786.

. Instituições de Direito Civil Português. Lisboa. 1789.

FOUCAULT, Michel. A história da sexualidade: a vontade de saber. v. 1. São Paulo: Graal, 1988.

Em defesa da sociedade. São Paulo: Martins Fontes, 1997.

Diálogo sobre o Poder. In:

Estratégia Poder-Saber. Rio de Janeiro: Forense

Universitária, 2010. p. 251-266. (Ditos e escritos IV). 
GAMEIRO, José Feliciano da Rocha. Edital da intendência Geral da Polícia, 23 de junho de 1808. Porto. 1808.

GOFFMAN, Erving. Manicômios, prisões e conventos. São Paulo: Perspectiva, 1961.

JAKOBSON, Roman. Decadência do cinema? In: Linguística. Poética. Cinema.

São Paulo: Perspectiva, 2015.

KOJEVE, Alexandre. Breve introdução à leitura de Hegel: a dialética do senhor e do escravo. Portugal: Presença, 1979.

LARANJO, José Frederico. O conteúdo e o critério do direito. Coimbra: Imprensa Litteraria, 1871.

LEITÃO, Joaquim. A peste: aspectos moraes da Epiddemia Nacional. Lisboa, 1889.

MACHADO, Maria Helena Pereira Toledo. O plano e o pânico: os movimentos sociais na década de abolição. São Paulo: Edusp, 2010.

NICOLAU, Emérico. O manual dos inquisidores. Lisboa: Afrodite, 1972.

PAIVA, Vicente Ferrer Neto de. Elementos de direitos das gentes. Coimbra: Imprensa da Universidade, 1843.

Revista Brasil-Médico.

ROSE, Nikolas. Powers of freedom: reframing political thought. United Kingdom: Cambridge University Press, 1999.

SCHELLING, Friedrich Wilhelm Joseph von. Filosofia da arte. São Paulo: Edusp, 2001.

SILVA, Márcia Regina Barros da. O laboratório e a República: saúde pública, ensino médico e produção de conhecimento em São Paulo (1891-1933). Rio de Janeiro: Fiocruz, 2014.

SOCIEDADE das Sciencias Médicas de Lisboa. Instrucções de prophylaxia individual contra o cholera asiático. Lisboa: Typographia de Christovão Augusto Rodrigues, 1884.

ZANONI, Fábio. A censura sem limites: as práticas de censura no cinema e seus ecos na contemporaneidade democrática luso-brasileira (1930-1950). Tese de doutorado defendida na Universidade de Lisboa, 2015. 